\title{
Synthesis, Characterization, and Cytotoxicity of Iron Oxide Nanoparticles
}

\author{
S. Kanagesan, ${ }^{1}$ M. Hashim, ${ }^{1}$ S. Tamilselvan, ${ }^{2}$ N. B. Alitheen, ${ }^{2}$ I. Ismail, ${ }^{1}$ \\ A. Hajalilou, ${ }^{1}$ and K. Ahsanul ${ }^{3}$ \\ ${ }^{1}$ Materials Synthesis and Characterization Laboratory (MSCL), Institute of Advanced Technology (ITMA), Universiti Putra Malaysia, \\ 43400 Serdang, Selangor, Malaysia \\ ${ }^{2}$ Department of Cell and Molecular Biology, Faculty of Biotechnology and Biomolecular Sciences, Universiti Putra Malaysia, \\ 43400 Serdang, Selangor, Malaysia \\ ${ }^{3}$ Department of Mechanical and Manufacturing Engineering, Faculty of Engineering, Universiti Putra Malaysia, 43400 Serdang, \\ Selangor, Malaysia
}

Correspondence should be addressed to S. Kanagesan; kanagu1980@gmail.com

Received 23 September 2013; Accepted 24 November 2013

Academic Editor: Steven Suib

Copyright (C) 2013 S. Kanagesan et al. This is an open access article distributed under the Creative Commons Attribution License, which permits unrestricted use, distribution, and reproduction in any medium, provided the original work is properly cited.

In order to study the response of human breast cancer cells' exposure to nanoparticle, iron oxide $\left(\alpha-\mathrm{Fe}_{2} \mathrm{O}_{3}\right)$ nanoparticles were synthesized by a simple low temperature combustion method using $\mathrm{Fe}\left(\mathrm{NO}_{3}\right)_{3} \cdot 9 \mathrm{H}_{2} \mathrm{O}$ as raw material. X-ray diffraction studies confirmed that the resultant powders are pure $\alpha-\mathrm{Fe}_{2} \mathrm{O}_{3}$. Transmission electron microscopy study revealed the spherical shape of the primary particles, and the size of the iron oxide nanoparticles is in the range of $19 \mathrm{~nm}$. The magnetic hysteresis loops demonstrated that the sample exposed ferromagnetic behaviors with a relatively low coercivity. The cytotoxicity of $\alpha-\mathrm{Fe}_{2} \mathrm{O}_{3}$ nanoparticle was also evaluated on human breast cancer cells to address the current deficient knowledge of cellular response to nanoparticle exposure.

\section{Introduction}

Recently, synthesis of oxide nanoparticles with homogeneous size has attracted a great deal of attention from researchers due to its unique optical, electrical, and magnetic properties and their potential interests in a variety of biomedical applications [1]. Iron oxides are very important materials, classified into three different forms, namely, hematite $(\alpha$ $\left.\mathrm{Fe}_{2} \mathrm{O}_{3}\right)$, maghemite $\left(\gamma-\mathrm{Fe}_{2} \mathrm{O}_{3}\right)$, and magnetite $\left(\mathrm{Fe}_{3} \mathrm{O}_{4}\right)$ [2]. Among them, hematite $\left(\alpha-\mathrm{Fe}_{2} \mathrm{O}_{3}\right)$ is a thermodynamically stable iron oxide under ambient conditions. It has the corundum structure and offers high resistance to corrosion. Its low cost and nontoxicity make it the most environmentally friendly $\mathrm{n}$-type semiconductor material (band gap of $2.1 \mathrm{eV}$ ) [3-7].

They hold bear have great scientific interest due to its various extensive technological applications such as magnetic recording media, catalysis, pigments, electrode materials, gas sensors, optical devices, electromagnetic devices, lithium ion battery electrodes, sorbents, and drug delivery [8-13].

The properties of $\alpha-\mathrm{Fe}_{2} \mathrm{O}_{3}$ strongly depend on the particle size, morphology, and its structure [14]. In order to obtain nanostructures of $\alpha-\mathrm{Fe}_{2} \mathrm{O}_{3}$ powder, several techniques have been designed such as thermal oxidation technique [15], hydrothermal processing [16], mechanical millings [17], microwave synthesis [18], and sol-gel [19]. Among these methods, sol-gel combustion method has simple synthesis procedure and is cost-effective. This method can result in ultrafine homogeneous powder [20]. Magnetic nanoparticles have displayed great promise for use as tools in a wide variety of biomedical applications including drug delivery in cancer chemotherapy.

Nanoparticles are attractive for cancer applications as they can be engineered to have multifunctionality serving simultaneously as imaging contrast agents, therapeutic agents, and drug delivery vehicles. Meanwhile, effects of 
nanoparticles on health and safety have also attracted more and more attention $[21,22]$. It is already known that nanoparticles of different sizes have different abilities of entering target cells. Some researches have reported that small-sized nanoparticles are more readily able to enter the cancer cells and interact with components inside the cells; hence, those nanoparticles may act as a good system for drug delivery and offer new perspectives for diagnostic and targeted therapeutic approaches for cancers [23, 24]. Furthermore, magnetic particles like $\mathrm{Fe}_{2} \mathrm{O}_{3}$ nanoparticles have excellent biocompatible properties and thus could be used to perform many in vitro and in vivo applications including resonance imaging [25]. Some reports have indicated that magnetic particles of iron oxide could be phagocytosed by cancer cells and interact with components inside the cells; hence, those magnetic nanoparticles may act as a good system for drug delivery and offer new perspectives for diagnostic and targeted therapeutic approaches for cancers [26, 27]. Several researchers have studied the toxic effects of metal nanoparticles and reported the changes in cellular morphology, mitochondrial function, and apoptosis [28-30]. Numerous metal nanoparticles exhibited cytotoxicity after exposure to cells, and $\mathrm{Fe}_{2} \mathrm{O}_{3}$ nanoparticles were found to be more potent [31-33]. It has been shown that iron oxide nanoparticle had no measurable cytotoxic effect at lower doses $(10-50 \mu \mathrm{g} / \mathrm{mL})$, while there was a significant effect at higher levels (100$250 \mu \mathrm{g} / \mathrm{mL}$ ) [34, 35]. Furthermore, Veranth and coworkers [36] studied the cytokine response in BEAS-2B cells due to metal oxide nanoparticles and found that metal oxide particles have a lower toxicity than an equal mass of micronsized particles of the same nominal composition. Despite the wide-spread application of magnetic nanoparticles, there is a serious lack of information concerning the toxicity of these nanoparticles at the cellular and molecular levels. Only a few significant studies reported the potential cytotoxicity of $\mathrm{Fe}_{2} \mathrm{O}_{3}$ nanoparticles [28-30]. In view of this, we have successfully synthesized $\alpha-\mathrm{Fe}_{2} \mathrm{O}_{3}$ nanoparticles by the simple sol-gel combustion method and have explored the cytotoxic effect on human breast cancer MCF-7 cells.

\section{Experimental Techniques}

2.1. Nanopowder Synthesis. In the typical procedure, $1 \mathrm{~mol}$ of $\mathrm{Fe}\left(\mathrm{NO}_{3}\right)_{3} \cdot 9 \mathrm{H}_{2} \mathrm{O}$ solution was added with $100 \mathrm{~mL}$ of ethylene glycol, and the mixture was continuously stirred at room temperature to get a clear brown-coloured solution. This solution was continuously stirred for $8 \mathrm{~h}$ at a temperature of $90^{\circ} \mathrm{C}$. Viscosity of the solution increased constantly with time. The reddish brown gel was calcinated at $250^{\circ} \mathrm{C}$ in a hot air oven for $24 \mathrm{~h}$. The resultant powder was subsequently washed several times with distilled water and ethanol. The structure, morphology, and magnetic properties of the asprepared sample were characterized by powder X-ray diffraction (XRD) and transmission electron microscopy (TEM). The magnetic characteristics of the specimen were measured at room temperature using a vibrating sample magnetometer (VSM) (LDJ9600).
2.2. Cell Proliferation Assays. MCF-7 cells, human breast cancer cells, were obtained from American Type Culture Collection, and the cells were grown in DMEM at $37^{\circ} \mathrm{C}$ under $5 \% \mathrm{CO}_{2}$ in a humidified incubator. Cells were harvested, counted, and transferred to 96-well plates and incubated for $24 \mathrm{~h}$ prior to the addition of the nanoparticle. The iron oxide nanoparticles were processed and applied in various concentrations, and the treated cells were incubated for $24 \mathrm{~h}$. MCF-7 cells were plated $\left(1 \times 10^{4}\right.$ cells/well $)$ in triplicate in 96-well sterile microtiter plates and allowed to grow for $24 \mathrm{~h}$ for proper cell adherence. Cells were then treated with different concentrations of iron oxide nanoparticles for $24 \mathrm{~h}$. Cells incubated with $25 \mu \mathrm{L}$ of PBS were used as a control. After incubation, the media were discarded and replaced with $175 \mu \mathrm{L}$ of fresh medium and $25 \mu \mathrm{L}$ of the MTT (3-[4,5-dimethylthiazol-2-yl]-2,5-diphenyltetrazolium bromide) solution then incubated at $37^{\circ} \mathrm{C}$ under $5 \% \mathrm{CO}_{2}$ for 4 hours. The medium was removed, and $100 \mu \mathrm{L}$ of dimethyl sulfoxide was added to solubilize the formazan crystals. Optical density was then taken at $575 \mathrm{~nm}$. The results were expressed as the percentage proliferation with respect to vehicle-treated cells.

2.3. Trypan Blue Exclusion Test. The trypan blue exclusion assay was performed to analyze the cell viability after $\alpha$ $\mathrm{Fe}_{2} \mathrm{O}_{3}$ nanoparticle treatment. Equal amounts of MCF-7 cell suspension and trypan blue (0.4\%) were mixed for 1-2 min and $10 \mu \mathrm{L}$ of the mixture was placed on hemocytometer and observed under light microscope, and the cells were counted in all four fields.

\subsection{Acridine Orange/Propidium Iodine (AO/PI) Staining.} MCF-7 cells were treated with various concentrations of $\alpha$ $\mathrm{Fe}_{2} \mathrm{O}_{3}$ nanoparticles and stained with AO/PI (Sigma-Aldrich) dual dye to detect apoptotic or necrotic nuclei. The cells were seeded in 6-well tissue culture plates for $24 \mathrm{~h}$ followed by the $\alpha-\mathrm{Fe}_{2} \mathrm{O}_{3}$ nanoparticle treatment at desired concentrations. After the incubation period, the media were removed, and the cells were washed twice with PBS. Fresh media were added in each well, and the cells were stained by adding $10 \mu \mathrm{L}$ of AO/PI mix ( $10 \mathrm{mg} \mathrm{mL}^{-1} \mathrm{AO}$ and $10 \mathrm{mg} \mathrm{mL}^{-1} \mathrm{PI}$ in PBS) then incubated for $10 \mathrm{~min}$. The cells were washed with PBS before visualizing under a fluorescence microscope (Nikon Eclipse, TS100, Tokyo) with an excitation filter of 480/30 nm.

2.5. Annexin V-PI Staining. The FITC annexin V staining was carried out to examine the induction of apoptosis in $\alpha-\mathrm{Fe}_{2} \mathrm{O}_{3}$ nanoparticles treated MCF-7 cells. In order to differentiate the necrotic cells from apoptotic ones, the iron oxide nanoparticle treated MCF-7 cells were simultaneously stained with PI. Cells were grown in 6 -well plates $(1 \times$ $10^{5}$ cells/well) and then incubated for $24 \mathrm{~h}$ in the presence of various doses of iron oxide nanoparticles. At the required time point, the cells were harvested and then stained with FITC annexin V-PI as per manufacturer's instructions (FITC Annexin V Apoptosis Detection Kit, BD Pharmingen, NJ) and analyzed in a FACS Calibur (BD Biosciences, NJ) flow 
cytometer. The results were analysed using CellQuest Pro software.

\section{Results and Discussion}

3.1. Structural Analysis. It is observed from Figure 1 that all the diffraction peaks can be readily indexed to the rhombohedral phase of hematite $\alpha-\mathrm{Fe}_{2} \mathrm{O}_{3}$. These diffraction patterns are in good agreement with Joint Committee on Powder Diffraction Standards (JCPDS) card number; 33-0664 with lattice parameters $a=5.035 \AA$ and $c=13.749 \AA$, matching well with the reported literature [37]. A small amount of extra secondary $\gamma-\mathrm{Fe}_{2} \mathrm{O}_{3}$ phase is observed at $2 \theta$ value of $30.7^{\circ}$. Significant line broadening of the diffraction peaks indicates that the sample's size is in $\mathrm{nm}$ range. The average crystallite size of $\alpha-\mathrm{Fe}_{2} \mathrm{O}_{3}$ was estimated to be about $20.6 \mathrm{~nm}$ using Debye-Scherrer's formula [38] $t=0.9 \lambda / \beta \cos \theta$, where $\lambda$ is the wavelength of $\mathrm{Cu}$-Ka radiation source, $\beta$ (in radians) is the full width at half maximum (FWHM) intensity of the diffraction peak line, and $\theta$ is the diffraction angle (Braggs angle) of the XRD spectra, calculated from the line broadening of the (104) diffraction peak.

3.2. Particle Size Analysis. Figure 2 shows typical TEM image of the $\alpha-\mathrm{Fe}_{2} \mathrm{O}_{3}$ nanopowder calcinated at $250^{\circ} \mathrm{C}$ during $24 \mathrm{~h}$. A good number of particles have spherical shapes, and their average size is measured to be in the range $19 \mathrm{~nm}$. This is in good agreement with the particle size calculated from Debye-Scherrer formula in the X-ray diffraction method. Agglomerations observed in the TEM image might be due to the addition of small drop of iron oxide particles on microgrid during specimen preparation. The variations in particle sizes as measured by X-ray diffraction and TEM image may be due to the fact that several crystal domains build a particle $[39,40]$.

3.3. Magnetic Analysis. Magnetic hysteresis behaviour (Figure 3) of $\alpha-\mathrm{Fe}_{2} \mathrm{O}_{3}$ nanopowder was carried out at room temperature with the applied magnetic field from 250 to 20,000 gauss. It is known that the magnetic properties of the $\alpha-\mathrm{Fe}_{2} \mathrm{O}_{3}$ powder were influenced by many factors such as particle size, shape, crystallinity, aspect ratio, synthesis conditions, the extent of cation substitution, and surface structure [41-46]. It can be seen from Figure 3 that the sample exhibits ferromagnetic behavior at room temperature. The saturation magnetization and coercivity values are $7.5 \mathrm{emu} / \mathrm{g}$ and 240 Oe, respectively. The inset image of Figure 3 shows a magnified view of original hysteresis loop of $\alpha-\mathrm{Fe}_{2} \mathrm{O}_{3}$ nanopowder. It is known that the coercivity is mainly influenced by many potential factors such as morphologies, size, surface disorder, and structure [45]. The sample's low coercivity value ( $240 \mathrm{Oe}$ ) may be due to high crystallinity and crystal defects [47]. Literature studies reveal that hematite exhibits antiferromagnetic behavior whereas maghemite exhibits ferromagnetic behavior at room temperature. The ferromagnetic properties of $\alpha-\mathrm{Fe}_{2} \mathrm{O}_{3}$ nanopowder can be explained by the ferromagnetic contribution of $\gamma-\mathrm{Fe}_{2} \mathrm{O}_{3}$ phase along with $\alpha-\mathrm{Fe}_{2} \mathrm{O}_{3}$ phase [48].

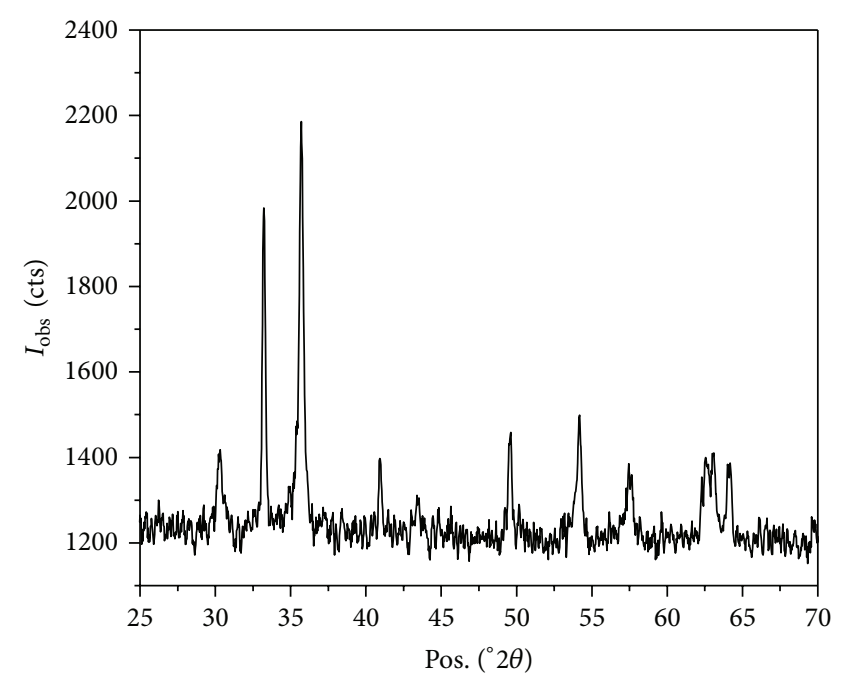

Figure 1: XRD pattern of the $\alpha-\mathrm{Fe}_{2} \mathrm{O}_{3}$ nanopowder.

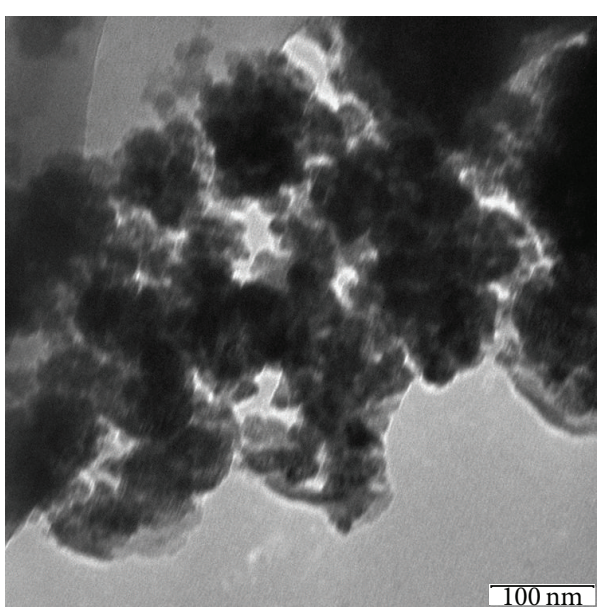

FIgURE 2: TEM micrograph of $\alpha-\mathrm{Fe}_{2} \mathrm{O}_{3}$ nanopowder.

3.4. Cytotoxicity Analysis. Human breast epithelial MCF-7 cells were exposed to $\alpha-\mathrm{Fe}_{2} \mathrm{O}_{3}$ nanoparticles at the concentrations of $25,50,100,200$, and $400 \mu \mathrm{g} / \mathrm{mL}$ for $24 \mathrm{~h}$ and cytotoxicity was determined using MTT assays. MTT results have shown that as the concentration of nanoparticles increased to 100,200 and $400 \mu \mathrm{g} / \mathrm{mL}$, cytotoxicity was observed in dose-dependent fashion. In MTT assay, cell viability was significantly reduced to $90 \%, 83 \%, 69 \%, 51 \%$ and $36 \%$ for the concentrations of $25,50,100,200$, and $400 \mu \mathrm{g} / \mathrm{mL}$, respectively $(P<0.05$ for each) (Figure 4 ). This inhibitory growth activity of the treated cells acted in a dose-dependent manner which was also confirmed by the cell viability with the trypan blue exclusion assay. Our cytotoxicity data is in accordance with the results of Hilger et al. [31]. They investigated the cytotoxic response of iron oxide nanoparticles to adenocarcinoma cells. Results showed that iron oxide nanoparticles at low concentration did not produce cytotoxicity while the higher concentrations 


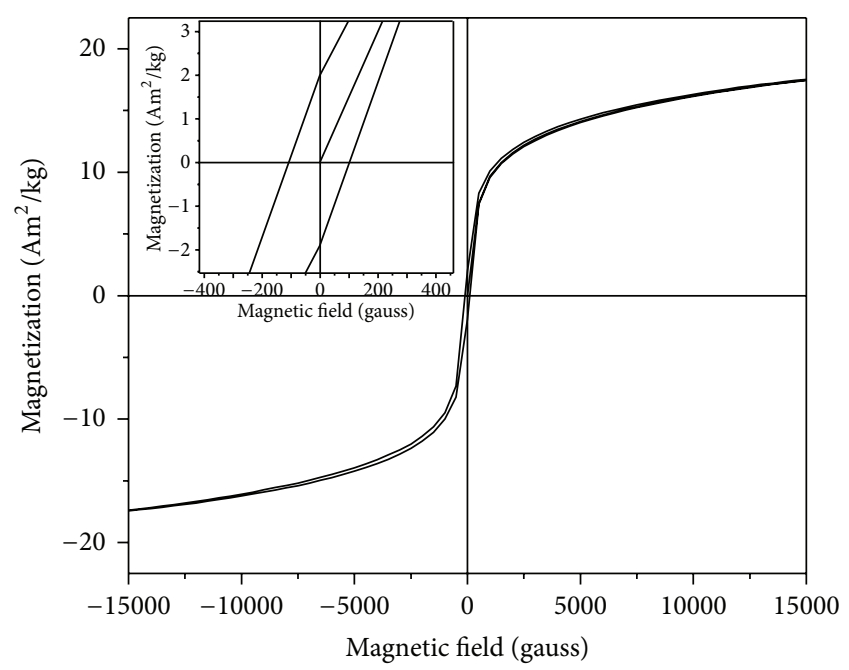

Figure 3: Hysteresis loop of $\alpha-\mathrm{Fe}_{2} \mathrm{O}_{3}$ nanopowder.

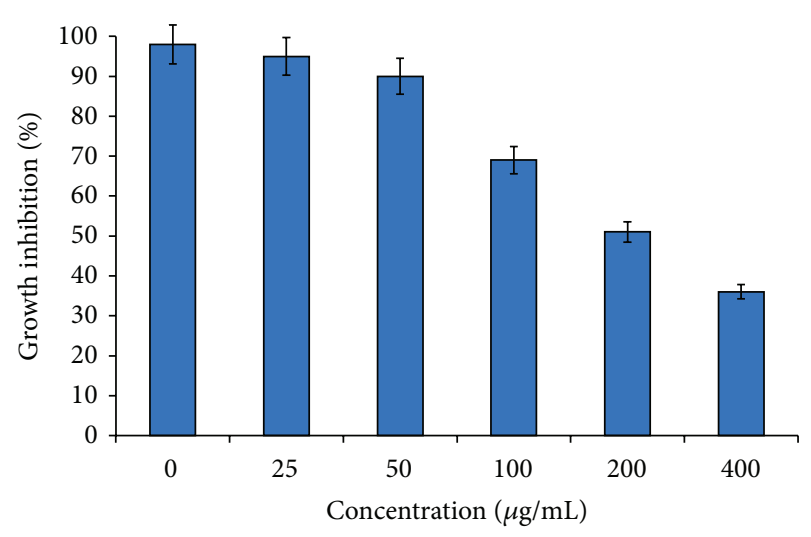

FIGURE 4: Effect of $\alpha-\mathrm{Fe}_{2} \mathrm{O}_{3}$ on the growth of breast cancer cell lines MCF-7. Cells are seeded in 96-well plates and incubated with different concentrations of $\alpha-\mathrm{Fe}_{2} \mathrm{O}_{3}$ and noted after $24 \mathrm{~h}$ maintaining at $37^{\circ} \mathrm{C}$. Cell viabilities are determined by $3-(4,5$-dimethylthiazol-2yl)-2,5-diphenyltetrazolium bromide (MTT) assay. Data points are presented as means \pm SD of triplicate experiments.

significantly reduced the viability of adenocarcinoma cells. As with most published work in nanotoxicology, the high concentration-induced cytotoxicity observed in this study may be difficult to translate to a realistic human exposure scenario. We believe that these data can provide a springboard for other researchers to create mechanistic pathways involved in cell death induced by iron oxide nanoparticles.

To investigate the mode of cell death (i.e. apoptosis or necrosis) in MCF-7 cells caused by the $\alpha-\mathrm{Fe}_{2} \mathrm{O}_{3}$, treated cells were stained with AO/PI dual dye and observed under the fluorescence microscope. Figure 5 shows that the cells treated with $25 \mu \mathrm{g} \mathrm{mL}{ }^{-1} \alpha-\mathrm{Fe}_{2} \mathrm{O}_{3}$, like the nontreated ones, are uniformly green with normal morphology. However, extensive nuclear margination accompanied with chromatin condensation and distinctive of apoptotic cell death $[49,50]$ was observed in treated cells at the $\alpha-\mathrm{Fe}_{2} \mathrm{O}_{3}$ concentrations of 100,200 , and $400 \mu \mathrm{g} \mathrm{mL}^{-1}$. The results of $\mathrm{AO} / \mathrm{PI}$ nuclear

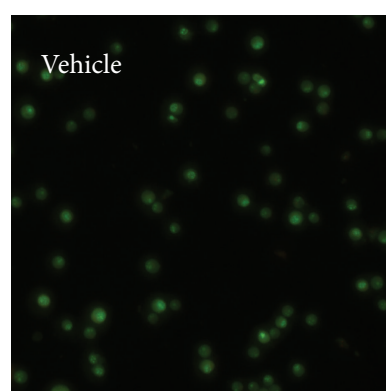

(a)

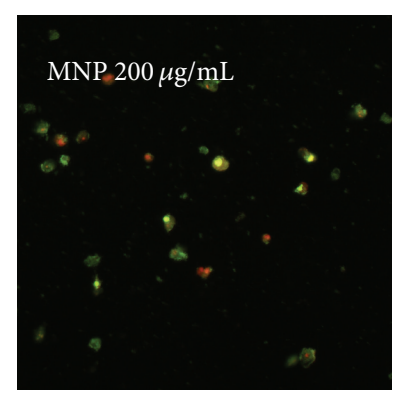

(c)

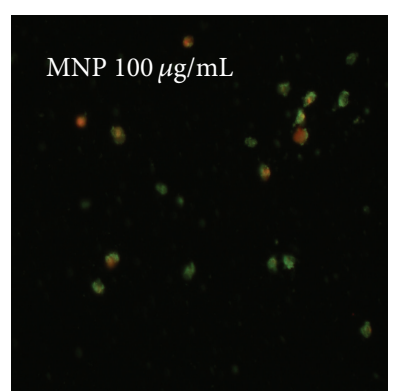

(b)

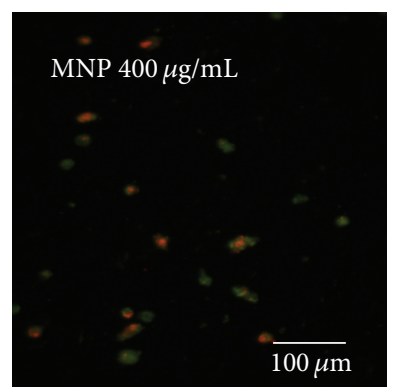

(d)
FIgURE 5: Morphological assessment of MCF-7 cells stained with acridine orange (green) and propidium iodide (red). Cells are incubated with or without $\alpha-\mathrm{Fe}_{2} \mathrm{O}_{3}$ at various concentrations for $24 \mathrm{~h}$. Cells with intact membrane and stained green indicate viable cells; cells that are stained orange represent secondary necrotic or late apoptotic cells containing fragmented DNA (magnification 100x, scale bar $20 \mu \mathrm{m}$ ).

staining indicated the induction of apoptosis in MCF-7 cells by $\alpha-\mathrm{Fe}_{2} \mathrm{O}_{3}$ (Figure 5). The apoptotic cell death in MCF-7 cells induced by $\alpha-\mathrm{Fe}_{2} \mathrm{O}_{3}$ was confirmed and subsequently quantified by flow cytometric analysis. Early apoptotic cells can easily be identified by green fluorescence of FITCconjugated annexin $\mathrm{V}$ as annexin $\mathrm{V}$ has a high affinity towards phosphatidylserine (PS) residues which are externalized from inner to outer leaflet of the plasma membrane during early stages of apoptosis $[51,52]$. Figure 6 shows the results of flow cytometric analysis of FITC annexin V-PI stained MCF-7 cells treated with different concentrations of $\alpha-\mathrm{Fe}_{2} \mathrm{O}_{3}$. The percentages of apoptotic and necrotic populations in treated and untreated cells were calculated from the flow cytometric data and the results clearly show the dose-dependent reduction in cell viability of MCF-7 cells in presence of $\alpha-\mathrm{Fe}_{2} \mathrm{O}_{3}$. Most importantly, the apoptotic and necrotic populations in MCF-7 cells increased by $34 \%, 61 \%$, and $86 \%$ in presence of 100,200 , and $400 \mu \mathrm{g} \mathrm{mL}^{-1} \alpha-\mathrm{Fe}_{2} \mathrm{O}_{3}$, respectively. The results of flow cytometric analysis clearly establish the efficient induction of apoptotic and necrotic cell death in MCF-7 cells by $\alpha-\mathrm{Fe}_{2} \mathrm{O}_{3}$ (Figure 6). While necrosis is a form of cell death resulting from direct cell damage, apoptosis is a form of programmed cell death where cells effectively commit suicide [53]. Our study demonstrates the simultaneous visualisation of viable, necrotic, and apoptotic cells in any given sample suggesting that iron oxide nanoparticles induce apoptosis and necrosis in dose-dependent manner. Similar effects have 


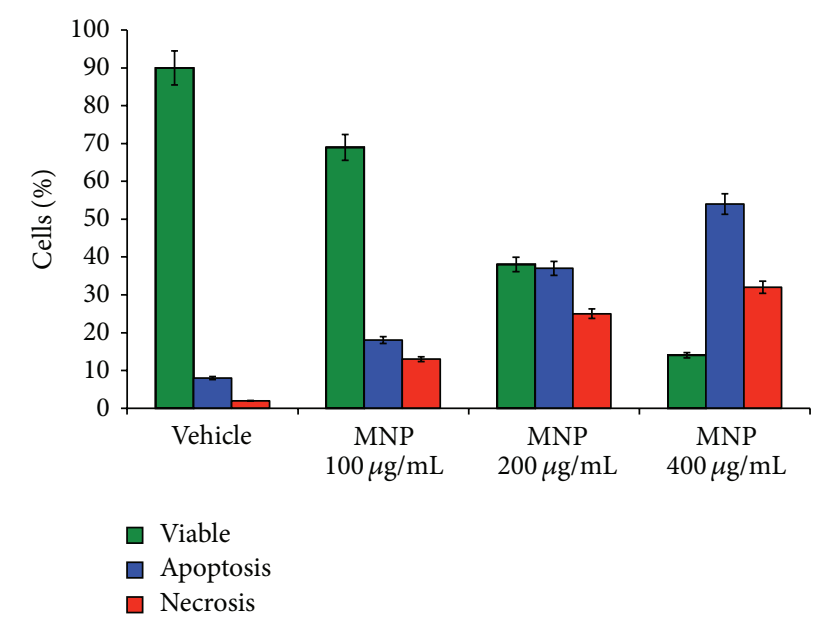

FIGURE 6: Flow cytometry analysis of untreated and treated MCF-7 cells with $\alpha-\mathrm{Fe}_{2} \mathrm{O}_{3}$ for $24 \mathrm{~h}$ stained with annexin V-FITC/propidium iodide (PI). Each bar represents the population of viable, apoptotic, and necrotic cells of three independent experiments.

been observed in other ferrofluids which employ oleic acid [54]. In the present case, the observed cytotoxic effects are more difficult to diagnose but are possibly due to free radical generation through Fenton and/or Haber-Weiss reactions whose effects only become noticeable at higher intracellular concentrations of iron [55]. Another possible explanation for the significant cytotoxicological and morphological changes is that the phenotypic effects of iron oxide internalization may drastically impede transcriptional regulation and protein synthesis resulting in a loss of cell phenotype and possibly cell death. It has been recently demonstrated that there are many factors such as size, shape, surface charge, and solubility influencing the nature of the nanoparticle corona and playing a vital role in the interaction of the nanoparticles with proteins. In vitro and in vivo studies suggested that these interactions between nanoparticles determine the fate and impact of the particles $[56,57]$. Furthermore, differences in the recent literature suggested that different cell types with different uptake mechanisms react differently to nanoparticle exposure $[58,59]$. In order to evaluate these possibilities, further studies into the physicochemical basis of the observed $\alpha-\mathrm{Fe}_{2} \mathrm{O}_{3}$ cytotoxicity, cellular uptake, and interaction of nanoparticles with proteins are necessary.

\section{Conclusion}

In conclusion, pure $\alpha-\mathrm{Fe}_{2} \mathrm{O}_{3}$ nanoparticles were synthesized by a low temperature combustion technique. The Xray powder diffraction measurement indicates that these particles are hematite. The ultrafine $\alpha-\mathrm{Fe}_{2} \mathrm{O}_{3}$ nanopowder shows a weak ferromagnetic behaviour and a significantly low coercivity performance because of their uniformity and small particle size. Cytotoxicity analysis demonstrates that the iron oxide nanoparticles lead to cellular morphological modifications and induce apoptosis and necrosis in a dosedependent manner. This preliminary data suggest that $\mathrm{Fe}_{2} \mathrm{O}_{3}$ nanoparticles are likely to contribute to cytotoxicity of human breast cancer cells and can be a potential candidate for drug delivery systems.

\section{References}

[1] P. Tartaj, M. D. P. Morales, S. Veintemillas-Verdaguer, T. González-Carreño, and C. J. Serna, "The preparation of magnetic nanoparticles for applications in biomedicine," Journal of Physics D, vol. 36, no. 13, pp. R182-R197, 2003.

[2] H. M. Fan, G. J. You, Y. Li et al., "Shape-controlled synthesis of single-crystalline $\mathrm{Fe}_{2} \mathrm{O}_{3}$ hollow nanocrystals and their tunable optical properties," Journal of Physical Chemistry C, vol. 113, no. 22, pp. 9928-9935, 2009.

[3] L. Song, S. Zhang, B. Chen, J. Ge, and X. Jia, "A hydrothermal method for preparation of $\alpha-\mathrm{Fe}_{2} \mathrm{O}_{3}$ nanotubes and their catalytic performance for thermal decomposition of ammonium perchlorate," Colloids and Surfaces A, vol. 360, no. 1-3, pp. 1-5, 2010.

[4] D. Peng, S. Beysen, Q. Li, Y. Sun, and L. Yang, "Hydrothermal synthesis of monodisperse $\alpha-\mathrm{Fe}_{2} \mathrm{O}_{3}$ hexagonal platelets," Particuology, vol. 8, no. 4, pp. 386-389, 2010.

[5] J. Hua and J. Gengsheng, "Hydrothermal synthesis and characterization of monodisperse $\alpha-\mathrm{Fe}_{2} \mathrm{O}_{3}$ nanoparticles," Materials Letters, vol. 63, no. 30, pp. 2725-2727, 2009.

[6] Y. Sun, G. Guo, B. Yang et al., "One-step solution synthesis of $\mathrm{Fe}_{2} \mathrm{O}_{3}$ nanoparticles at low temperature," Physica B, vol. 406, no. 4, pp. 1013-1016, 2011.

[7] M. V. Kovalenko, M. I. Bodnarchuk, R. T. Lechner, G. Hesser, F. Schäffler, and W. Heiss, "Fatty acid salts as stabilizers in sizeand shape-controlled nanocrystal synthesis: the case of inverse spinel iron oxide," Journal of the American Chemical Society, vol. 129, no. 20, pp. 6352-6353, 2007.

[8] W. Sun, Q. Meng, L. Jing, D. Liu, and Y. Cao, "Facile synthesis of surface-modified nanosized $\alpha-\mathrm{Fe}_{2} \mathrm{O}_{3}$ as efficient visible photocatalysts and mechanism insight," Journal of Physical Chemistry C, vol. 117, no. 3, pp. 1358-1365, 2013.

[9] S. Agarwala, Z. H. Lim, E. Nicholson, and G. W. Ho, "Probing the morphology-device relation of $\mathrm{Fe}_{2} \mathrm{O}_{3}$ nanostructures towards photovoltaic and sensing applications," Nanoscale, vol. 4, no. 1, pp. 194-205, 2012.

[10] S.-W. Cao, Y.-J. Zhu, G.-F. Cheng, and Y.-H. Huang, "Preparation and photocatalytic property of $\alpha-\mathrm{Fe}_{2} \mathrm{O}_{3}$ hollow core/shell hierarchical nanostructures," Journal of Physics and Chemistry of Solids, vol. 71, no. 12, pp. 1680-1683, 2010.

[11] L. Huang and H. Fan, "Room-temperature solid state synthesis of $\mathrm{ZnO} / \alpha-\mathrm{Fe}_{2} \mathrm{O}_{3}$ hierarchical nanostructures and their enhanced gas-sensing properties," Sensors and Actuators B, vol. 171-172, pp. 1257-1263, 2012.

[12] D. S. Toledano and V. E. Henrich, "Kinetics of $\mathrm{SO}_{2}$ adsorption on photoexcited $\alpha-\mathrm{Fe}_{2} \mathrm{O}_{3}$," Journal of Physical Chemistry B, vol. 105, no. 18, pp. 3872-3877, 2001.

[13] Y. Chen, H. Chen, D. Zeng et al., "Core/shell structured hollow mesoporous nanocapsules: a potential platform for simultaneous cell imaging and anticancer drug delivery," ACS Nano, vol. 4, no. 10, pp. 6001-6013, 2010.

[14] B. Sun, J. Horvat, H. S. Kim, W.-S. Kim, J. Ahn, and G. Wang, "Synthesis of mesoporous $\alpha-\mathrm{Fe}_{2} \mathrm{O}_{3}$ nanostructures for highly sensitive gas sensors and high capacity anode materials in lithium ion batteries," Journal of Physical Chemistry C, vol. 114, no. 44, pp. 18753-18761, 2010. 
[15] X. Su, C. Yu, and C. Qiang, "Synthesis of $\alpha-\mathrm{Fe}_{2} \mathrm{O}_{3}$ nanobelts and nanoflakes by thermal oxidation and study to their magnetic properties," Applied Surface Science, vol. 257, no. 21, pp. 90149018, 2011.

[16] C.-Y. Yin, M. Minakshi, D. E. Ralph, Z.-T. Jiang, Z. Xie, and H. Guo, "Hydrothermal synthesis of cubic $\alpha-\mathrm{Fe}_{2} \mathrm{O}_{3}$ microparticles using glycine: surface characterization, reaction mechanism and electrochemical activity," Journal of Alloys and Compounds, vol. 509, no. 41, pp. 9821-9825, 2011.

[17] O. M. Lemine, "Microstructural characterisation of $\alpha-\mathrm{Fe}_{2} \mathrm{O}_{3}$ nanoparticles using, XRD line profiles analysis, FE-SEM and FT-IR," Superlattices and Microstructures, vol. 45, no. 6, pp. 576$582,2009$.

[18] X. Zhang and Q. Li, "Microwave assisted hydrothermal synthesis and magnetic property of hematite nanorods," Materials Letters, vol. 62, no. 6-7, pp. 988-990, 2008.

[19] G. Xue, C. Gong, D. Chen, and X. Jiao, "Sol-gel related solvothermal procedure to prepare iron oxide fibers," Journal of Dispersion Science and Technology, vol. 28, no. 8, pp. 1173-1177, 2007.

[20] P. Sivakumar, R. Ramesh, A. Ramanand, S. Ponnusamy, and C. Muthamizhchelvan, "Synthesis and characterization of nickel ferrite magnetic nanoparticles," Materials Research Bulletin, vol. 46, no. 12, pp. 2208-2211, 2011.

[21] K. M. Vasquez and J. H. Wilson, "Triplex-directed modification of genes and gene activity," Trends in Biochemical Sciences, vol. 23, no. 1, pp. 4-9, 1998.

[22] R. V. Guntaka, B. R. Varma, and K. T. Weber, "Triplexforming oligonucleotides as modulators of gene expression," International Journal of Biochemistry and Cell Biology, vol. 35, no. 1, pp. 22-31, 2003.

[23] I. Brigger, C. Dubernet, and P. Couvreur, "Nanoparticles in cancer therapy and diagnosis," Advanced Drug Delivery Reviews, vol. 54, no. 5, pp. 631-651, 2002.

[24] J. Kreuter, "Nanoparticulate systems for brain delivery of drugs," Advanced Drug Delivery Reviews, vol. 47, no. 1, pp. 65-81, 2001.

[25] J. R. Griffiths and J. D. Glickson, "Monitoring pharmacokinetics of anticancer drugs: non-invasive investigation using magnetic resonance spectroscopy," Advanced Drug Delivery Reviews, vol. 41, no. 1, pp. 75-89, 2000.

[26] T. K. Jain, M. A. Morales, S. K. Sahoo, D. L. Leslie-Pelecky, and V. Labhasetwar, "Iron oxide nanoparticles for sustained delivery of anticancer agents," Molecular Pharmaceutics, vol. 2, no. 3, pp. 194-205, 2005.

[27] K. Wagner, A. Kautz, M. Röder et al., "Synthesis of oligonucleotide-functionalized magnetic nanoparticles and study on their in vitro cell uptake," Applied Organometallic Chemistry, vol. 18, no. 10, pp. 514-519, 2004.

[28] S. M. Moghimi, A. C. Hunter, and J. C. Murray, "Longcirculating and target-specific nanoparticles: theory to practice," Pharmacological Reviews, vol. 53, no. 2, pp. 283-318, 2001.

[29] I. Willner and B. Willner, "Functional nanoparticle architectures for sensoric, optoelectronic, and bioelectronic applications," Pure and Applied Chemistry, vol. 74, no. 9, pp. 1773-1783, 2002.

[30] P. A. Dresco, V. S. Zaitsev, R. J. Gambino, and B. Chu, "Preparation and properties of magnetite and polymer magnetite nanoparticles," Langmuir, vol. 15, no. 6, pp. 1945-1951, 1999.

[31] I. Hilger, S. Frühauf, W. Linß et al., "Cytotoxicity of selected magnetic fluids on human adenocarcinoma cells," Journal of Magnetism and Magnetic Materials, vol. 261, no. 1-2, pp. 7-12, 2003.
[32] H. A. Jeng and J. Swanson, "Toxicity of metal oxide nanoparticles in mammalian cells," Journal of Environmental Science and Health: Part A, vol. 41, no. 12, pp. 2699-2711, 2006.

[33] M. Mahmoudi, A. Simchi, and M. Imani, "Cytotoxicity of uncoated and polyvinyl alcohol coated superparamagnetic iron oxide nanoparticles," Journal of Physical Chemistry C, vol. 113, no. 22, pp. 9573-9580, 2009.

[34] S. M. Hussain, K. L. Hess, J. M. Gearhart, K. T. Geiss, and J. J. Schlager, "In vitro toxicity of nanoparticles in BRL 3A rat liver cells," Toxicology in Vitro, vol. 19, no. 7, pp. 975-983, 2005.

[35] M. Mahmoudi, A. Simchi, A. S. Milani, and P. Stroeve, "Cell toxicity of superparamagnetic iron oxide nanoparticles," Journal of Colloid and Interface Science, vol. 336, no. 2, pp. 510-518, 2009.

[36] J. M. Veranth, E. G. Kaser, M. M. Veranth, M. Koch, and G. S. Yost, "Cytokine responses of human lung cells (BEAS-2B) treated with micron-sized and nanoparticles of metal oxides compared to soil dusts," Particle and Fibre Toxicology, vol. 4, article 2, 2007.

[37] R. Ramesh, Synthesis and surface coating/functionalization of iron oxide nanoparticles and study of their properties [Ph.D. thesis], SRM University, Chennai, India, 2012.

[38] P. Klug and L. E. Alexander, X-Ray Diffraction Procedure, John Wiley \& Sons, New York, NY, USA, 1954.

[39] R. K. Gupta, K. Ghosh, L. Dong, and P. K. Kahol, "Green synthesis of hematite $\left(\alpha-\mathrm{Fe}_{2} \mathrm{O}_{3}\right)$ submicron particles," Materials Letters, vol. 64, no. 19, pp. 2132-2134, 2010.

[40] C. Vázquez-vázquez, M. Carmen Blanco, M. A. López-quintela, R. D. Sánchez, J. Rivas, and S. B. Oseroff, "Characterization of $\mathrm{La}_{0.67} \mathrm{Ca}_{0.33} \mathrm{MnO}_{3 \pm \delta}$ particles prepared by the sol-gel route," Journal of Materials Chemistry, vol. 8, no. 4, pp. 991-1000, 1998.

[41] X. Xie, H. Yang, F. Zhang et al., "Synthesis of hollow microspheres constructed with $\alpha-\mathrm{Fe}_{2} \mathrm{O}_{3}$ nanorods and their photocatalytic and magnetic properties," Journal of Alloys and Compounds, vol. 477, no. 1-2, pp. 90-99, 2009.

[42] C. Rath, K. K. Sahu, S. D. Kulkarni et al., "Microstructuredependent coercivity in monodispersed hematite particles," Applied Physics Letters, vol. 75, no. 26, pp. 4171-4173, 1999.

[43] K. K. Sahu, C. Rath, N. C. Mishra, S. Anand, and R. P. Das, "Microstructural and magnetic studies on hydrothermally prepared hematite," Journal of Colloid and Interface Science, vol. 185, no. 2, pp. 402-410, 1997.

[44] F. Bødker and S. Mørup, "Size dependence of the properties of hematite nanoparticles," Europhysics Letters, vol. 52, no. 2, pp. 217-223, 2000.

[45] T. P. Raming, A. J. A. Winnubst, C. M. Van Kats, and A. P. Philipse, "The synthesis and magnetic properties of nanosized hematite $\left(-\mathrm{Fe}_{2} \mathrm{O}_{3}\right)$ particles," Journal of Colloid and Interface Science, vol. 249, no. 2, pp. 346-350, 2002.

[46] A. S. Teja and P.-Y. Koh, "Synthesis, properties, and applications of magnetic iron oxide nanoparticles," Progress in Crystal Growth and Characterization of Materials, vol. 55, no. 1-2, pp. 22-45, 2009.

[47] H. Qi, J. Ye, N. Tao, M. Wen, and Q. Chen, "Synthesis of octahedral magnetite microcrystals with high crystallinity and low coercive field," Journal of Crystal Growth, vol. 311, no. 2, pp. 394-398, 2009.

[48] P. Ayyub, M. Multani, M. Barma, V. R. Palkar, and R. Vijayaraghavan, "Size-induced structural phase transitions and hyperfine properties of microcrystalline $\mathrm{Fe}_{2} \mathrm{O}_{3}$," Journal of Physics C, vol. 21, no. 11, pp. 2229-2245, 1988. 
[49] S. Rello, J. C. Stockert, V. Moreno et al., "Morphological criteria to distinguish cell death induced by apoptotic and necrotic treatments," Apoptosis, vol. 10, no. 1, pp. 201-208, 2005.

[50] R. T. Allen, W. J. Hunter III, and D. K. Agrawal, "Morphological and biochemical characterization and analysis of apoptosis," Journal of Pharmacological and Toxicological Methods, vol. 37, no. 4, pp. 215-228, 1997.

[51] S. J. Martin, C. P. M. Reutelingsperger, A. J. McGahon et al., "Early redistribution of plasma membrane phosphatidylserine is a general feature of apoptosis regardless of the initiating stimulus: inhibition by overexpression of Bcl-2 and Abl," Journal of Experimental Medicine, vol. 182, no. 5, pp. 1545-1556, 1995.

[52] G. Koopman, C. P. Reutelingsperger, G. A. Kuijten, R. M. Keehnen, S. T. Pals, and M. H. Van Oers, "Annexin V for flow cytometric detection of phosphatidylserine expression on $\mathrm{B}$ cells undergoing apoptosis," Blood, vol. 84, no. 5, pp. 1415-1420, 1994.

[53] N. Ueda and S. V. Shah, "Apoptosis," Journal of Laboratory and Clinical Medicine, vol. 124, no. 2, pp. 169-177, 1994.

[54] K. J. Davies, S. Wells, and S. W. Charles, "The effect of temperature and oleate adsorption on the growth of maghemite particles," Journal of Magnetism and Magnetic Materials, vol. 122, no. 1-3, pp. 24-28, 1993.

[55] M. C. R. Symons and J. M. C. Gutteridge, Free Radicals and Iron: Chemistry, Biology and Medicine, Oxford University Press, Oxford, UK, 1998.

[56] M. P. Monopoli, D. Walczyk, A. Campbell et al., "Physicalchemical aspects of protein corona: relevance to in vitro and in vivo biological impacts of nanoparticles," Journal of the American Chemical Society, vol. 133, no. 8, pp. 2525-2534, 2011.

[57] J. Rauch, W. Kolch, S. Laurent, and M. Mahmoudi, "Big signals from small particles: regulation of cell signaling pathways by nanoparticles," Chemical Reviews, vol. 113, no. 5, pp. 3391-3406, 2013.

[58] M. Mahmoudi, H. Hofmann, B. Rothen-Rutishauser, and A. Petri-Fink, "Assessing the in vitro and in vivo toxicity of superparamagnetic iron oxide nanoparticles," Chemical Reviews, vol. 112, no. 4, pp. 2323-2338, 2012.

[59] S. Laurent, C. Burtea, C. Thirifays, U. O. Häfeli, and M. Mahmoudi, "Crucial ignored parameters on nanotoxicology: the importance of toxicity assay modifications and 'cell vision," PLoS One, vol. 7, no. 1, Article ID e29997, 2012. 

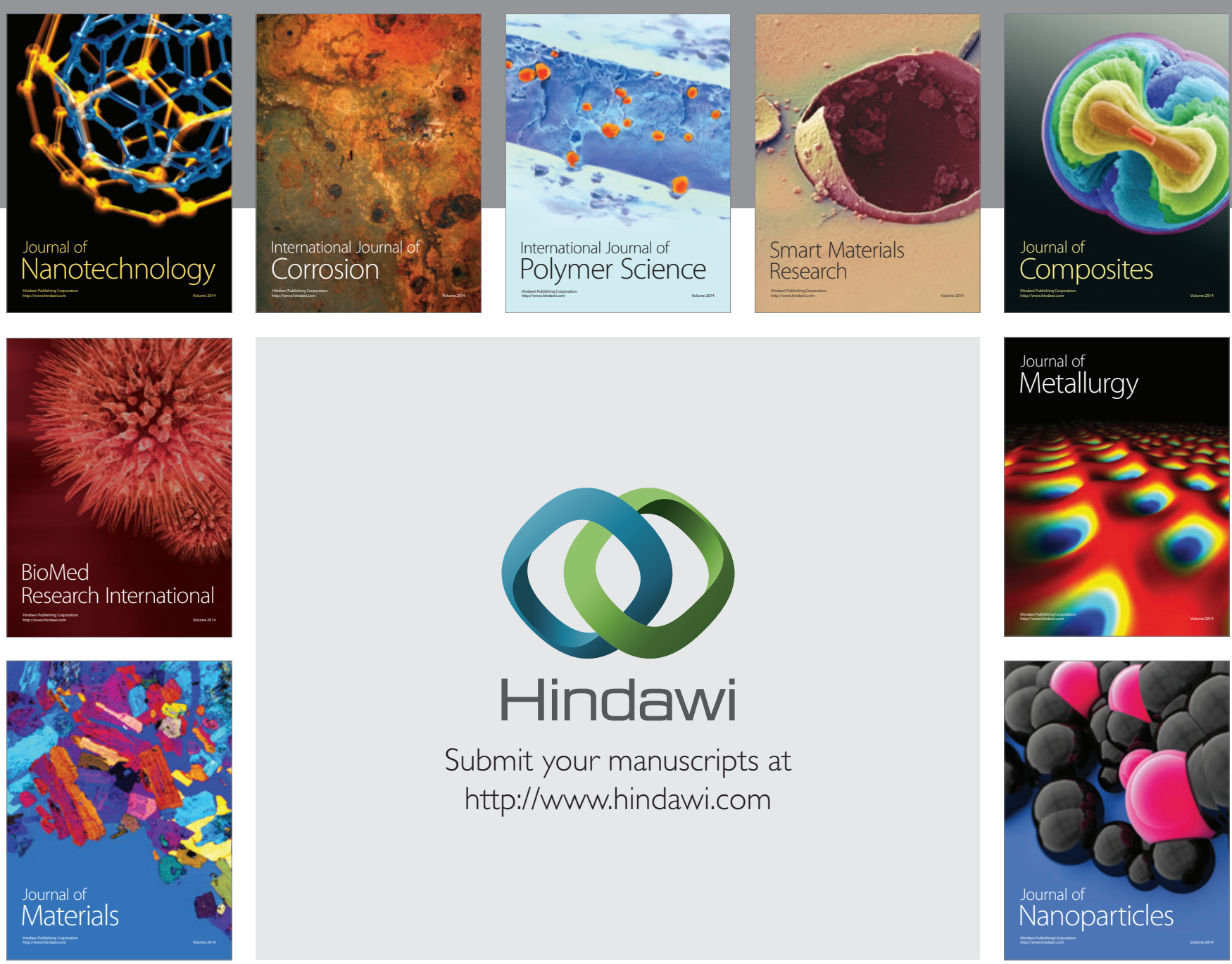

Submit your manuscripts at http://www.hindawi.com
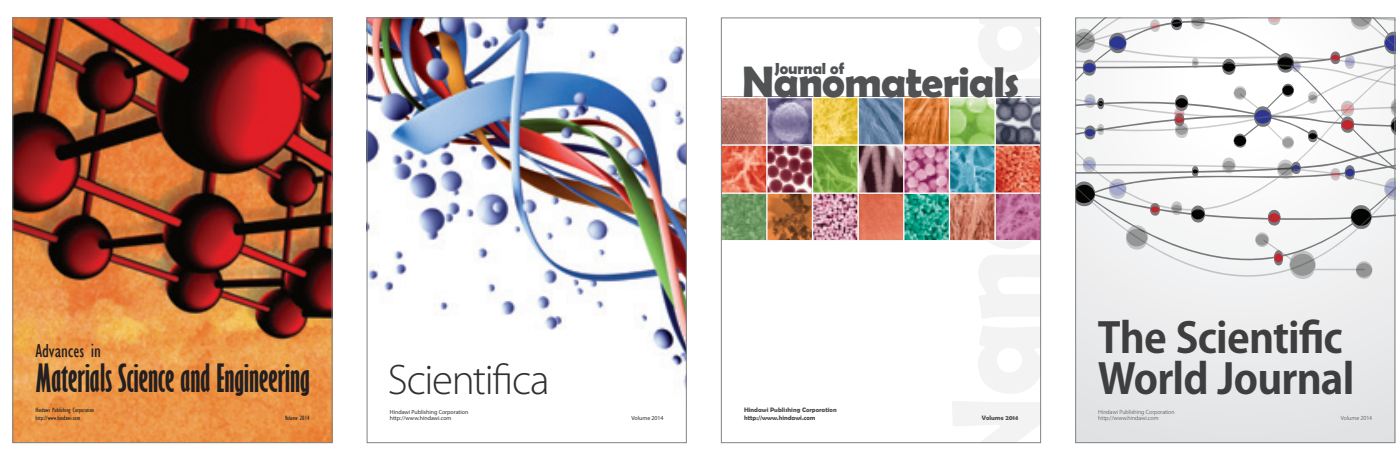

\section{The Scientific World Journal}
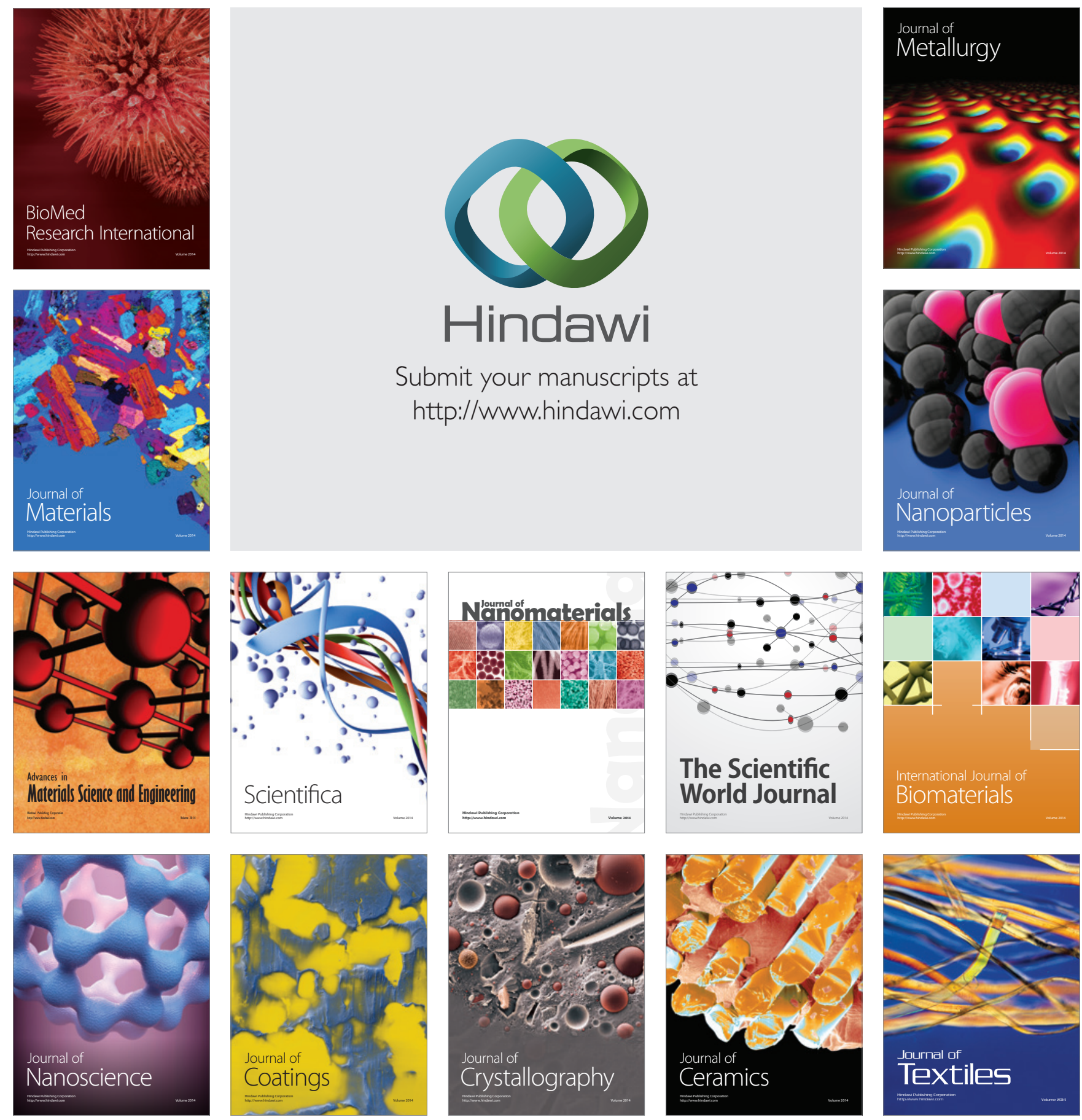